Journal of Southeast Asian

\title{
Vietnamese Americans: History, Education, and Societal Context
}

Stacy M. Kula

Azusa Pacific University, stacy.m.kula@gmail.com

Vinh Q. Tran

Claremont Graduate University, vinh.tran@cgu.edu

Iraise Garcia

Claremont Graduate University, iraise.garcia@cgu.edu

Erika Saito

National University, lerika.saito@gmail.com

Susan J. Paik

Claremont Graduate University, susan.paik@cgu.edu

Follow this and additional works at: https://docs.lib.purdue.edu/jsaaea

Part of the Bilingual, Multilingual, and Multicultural Education Commons

\section{Recommended Citation}

Kula, Stacy M.; Tran, Vinh Q.; Garcia, Iraise; Saito, Erika; and Paik, Susan J. (2021) "Vietnamese Americans: History, Education, and Societal Context," Journal of Southeast Asian American Education and Advancement: Vol. 16 : Iss. 1, Article 14.

DOI: $10.7771 / 2153-8999.1201$

Available at: https://docs.lib.purdue.edu/jsaaea/vol16/iss1/14

This document has been made available through Purdue e-Pubs, a service of the Purdue University Libraries. Please contact epubs@purdue.edu for additional information.

This is an Open Access journal. This means that it uses a funding model that does not charge readers or their institutions for access. Readers may freely read, download, copy, distribute, print, search, or link to the full texts of articles. This journal is covered under the CC BY-NC-ND license. 


\title{
ISAAEA Journal of Southeast Asian American Education and Advancement
}

Vol. 16 Iss. 1 (2021)

WWW.JSAAEA.org

\section{Vietnamese Americans: History, Education, and Societal Context}

\author{
Stacy M. Kula ${ }^{\mathrm{a}}$, Vinh Q. Tran ${ }^{\mathrm{b}}$, Iraise E. Garcia ${ }^{\mathrm{b}}$, L. Erika Saito ${ }^{\mathrm{c}}$, and Susan J. Paik ${ }^{\mathrm{b}}$ \\ ${ }^{a}$ Azusa Pacific University; ${ }^{b}$ Claremont Graduate University; ${ }^{c}$ National University
}

\begin{abstract}
While Asian Americans are often depicted as one high-achieving group, there are in fact a wide diversity of Asian American populations that each have their own history and acculturation experiences in the United States. Vietnamese Americans are a particularly unique group; having come with other Southeast Asian refugee groups after the Vietnam War, they are a relatively recent addition to U.S. society with very different circumstances of arrival in comparison with groups from other regions of Asia. This article takes a historical lens to understand the unique factors surrounding Vietnamese American entry to the United States-including policy, societal reception, co-ethnic community, and other barriers and opportunities - that shaped acculturation experiences for this group, influencing their subsequent educational and occupational outcomes.
\end{abstract}

Keywords: Vietnamese American, Acculturation, Historical analysis, Educational achievement, Modes of incorporation, Southeast Asian American

\section{Introduction}

Asian Americans have often been depicted as high achieving in both the popular media and a large portion of academic literature until recently (Paik et al., 2017; Poon et al., 2016; Shih et al., 2019). The problem with such narratives is it oversimplifies the variations in academic performance within and among the many Asian ethnic groups (Lee, 2015). Such a "model minority" stereotype can deprive the most vulnerable Asian American students of necessary educational assistance due to the assumption of their superior academic capability (Kagawa-Singer et al., 2011; Pang et al., 2011). More broadly, it can also lead to a lack of political support in terms of access to educational programs or funding for services for Asian American groups at local, state, or federal levels (Paik et al., 2014).

\footnotetext{
@)

SDRERIIGHISRESERNEDReaders are free to copy, display, and distribute this article, as long as the work is attributed to the author(s) and the Journal of Southeast Asian American Education \& Advancement, it is distributed for non-commercial purposes only, and no alteration or transformation is made in the work. More details of this Creative Commons license are available at http://creativecommons.org/licenses/by-nc-nd/3.0/. All other uses must be approved by the author(s) or JSAAEA. Journal of Southeast Asian American Education \& Advancement, Vol. 16. Iss. 1. (2021) ISSN: 2153-8999
} 
Recent academic work on Asian American achievement in the past decade have discussed the issue of masked diversity (Paik et al., 2014; Paik et al., 2017). Nonetheless, Asian Americans are often still clumped together as one, especially when other racial/ethnic groups are part of the research (Kagawa-Singer et al., 2011; Pang et al., 2011). Hence, it is vital that data on Asian Americans be disaggregated, and that research focus on specific communities; this enables an understanding of the specific trajectories in academic performance and career pathways for these groups - in this case, Vietnamese Americans (Kula \& Paik, 2016; Museus, 2013; Ngo \& Lee, 2007). When thinking of Asian groups by region, Southeast Asian groups who immigrated as a result of the Vietnam War have experienced the most divergent educational outcomes (Paik et al., 2014), and the Vietnamese community is by far the largest of these groups. Their more recent and more complex history in the United States warrants further investigation into how factors of immigration and incorporation may have played a role in their educational outcomes.

According to the 2017 American Community Survey, there are over 18 million Asian Americans in the United States, and those identifying as Vietnamese constitute the fourth largest ethnic group within this population, behind Chinese, Indians, and Filipinos (U.S. Census Bureau, 2017). Compared to other Asian groups, Vietnamese and other Southeast Asian Americans did not have a significant presence in the United States until the end of the Vietnam War (Ngo \& Lee, 2007; Takaki, 1998). Since then, Vietnamese Americans have integrated into the social fabric of American society while bringing with them their unique historical, social, and educational experiences.

Historical analyses yield useful insights and perspectives on the immigration experiences of Vietnamese Americans for future educational research (Paik et al., 2014). Therefore, this paper aims at exploring the immigration experiences of Vietnamese Americans through a historical lens in order to understand their current social situation in the United States and their academic performance patterns. In doing so, the paper reviews the extant literature on the factors of Vietnamese immigration and incorporation in the United States, analyzing these factors in a new and systematic way through the framework to understand how they broadly explain educational patterns for this group today.

\section{Theoretical Framework: Modes of Incorporation}

This paper utilizes the Asian American modes of incorporation model, developed by Paik et al. (2014), who adapted the early work of Portes and Rumbaut $(2014,2001)$ to Asian American immigrant experiences, acculturation patterns, and educational outcomes. In particular, the model is used here to explore the historical, social, and political contexts of Vietnamese immigrant experiences. General descriptions of the factors in the model and detailed information on Vietnamese American communities are provided in the following sections.

\section{Government Policy}

Immigration and related policies can be categorized as receptive, indifferent, or hostile (Portes \& Rumbaut, 2014, 2001). Receptive policies encourage the targeted group to immigrate to the United States, often with assistance or other incentive programs. Early waves of Southeast 
Asians, who were primarily Vietnamese, fall under this category (Paik et al., 2014). Indifferent policies allow pathways for legal immigration but without assistance for settlement, while hostile government policies actively prevent immigrants from coming by creating legal obstacles.

\section{Societal Reception}

Another significant factor related to acculturation experiences of an immigrant group is the level of acceptance from society, which can range from non-prejudiced, to neutral, to prejudiced. A nonprejudiced reception is positive in nature and would describe a welcoming posture by U.S. society in relation to immigration. A neutral reception relates to relative indifference - an incoming group might experience no active discrimination but would also not feel specifically welcomed into U.S. society - while a prejudiced reception would be characterized by discriminatory behavior of U.S. society toward a group based on negative stereotypes or general negative sentiment toward an incoming group. This factor helps to determine the quantity and quality of available jobs or other opportunities for the immigrant populations, as hiring practices might vary based on employers' receptivity (in a non-prejudiced context) or reticence (in a prejudiced context) to hire immigrants from a particular group. Discrimination, for example, may limit employment opportunities that lead to professional and social downgrades for immigrants in coming to the United States. Vietnamese Americans generally experienced prejudiced reception, despite some initial favorable engagement with volunteer organizations (Paik et al., 2014).

\section{Co-ethnic Community}

The strength of co-ethnic communities refers to the potential sources of human, social, and cultural capital concentrated within each immigrant group, which can provide a buffer for barriers encountered by new immigrants, such as a lack of educational or economic opportunities (Paik et al., 2014; Portes \& Rumbaut, 2001). The community can be categorized as strong, weak, or dispersed, depending on the concentration of the community into enclaves, as well as the socioeconomic quality of such cohorts. Co-ethnic communities characterized as strong exhibit high levels of human and cultural capital, meaning that their members tend to have high levels of education and/or occupational expertise; such groups with concentrations of professionals and entrepreneurs are able to secure jobs in specialized fields or start businesses that benefit their own communities. Asian groups that are composed primarily of low-skilled laborers with less education are classified as weak, as their jobs are less likely to provide upward mobility for co-ethnic members and are also more susceptible to the effects of discrimination. Co-ethnic communities are dispersed if they do not tend to live in ethnic enclaves at all; in such cases, their members tend to rely on their individual human, social, and cultural capital to secure educational and occupational success.

The terms "strong co-ethnic community" and "weak co-ethnic community" should not be confused with a sense of community, since Asian Americans are generally collectivist with strong ties to their ethnic groups; instead, these terms speak to the ways in which co-ethnic communities can provide their own opportunities for upward mobility. Paik et al. (2014) found that the initial wave of Vietnamese immigrants, mostly political refugees, despite their arrival with little capital and geographic distribution across the United States, were able to fairly quickly move to enclaves, utilizing their skills and educational backgrounds to effectively establish strong co-ethnic communities in these areas (Kula \& Paik, 2016; Takaki, 1998). 


\section{Other Barriers \& Opportunities}

There are other factors crucial to understanding Asian American immigration experiences (Paik et al., 2014). As the Vietnamese community arrived after 1965, they faced fewer challenges and barriers in terms of government policies than other Asian groups that came earlier when immigration from Asia was highly restricted (Chan, 1991; Takaki, 1998). The location or settlement pattern is another determining factor of the immigration experience. States like California or Texas provide greater resources to large co-ethnic communities and less pressure to acculturate than more rural areas with fewer resources (Chan, 1991; Portes \& Rumbaut, 2014, 2001; Takaki, 1998). Socioeconomic status (SES), occupation, and educational levels upon arrival to the United States are also significant. Generally, higher levels of education, more professional skills, or better class status can afford immigrants with more resources and opportunities. Lastly, English-language fluency may help reduce obstacles to integrate into mainstream America.

\section{Education Outcomes}

Together, the factors of the Asian American modes of incorporation (Paik et al., 2014), described above, provide an overall explanatory model for the differences in educational outcomes for diverse groups. Academic attainment is controlled by a complex set of direct and indirect factors. Historical, social, and political variations can be instructive in depicting the immigration experiences as well as examining their pathways to access human, social, and cultural capital. While many early Asian immigrant groups are now considered high performers in the United States, Vietnamese Americans have shown mixed results in terms of academic achievement, having both high- and low-achieving students (David et al., 2017; Ngo \& Lee, 2007; Takei et al., 2013;). However, the population has fared notably better in schools than other Southeast Asian groups (Kula \& Paik, 2016). The following sections will explore the application of this model to the Vietnamese American population, demonstrating its utility in broadly explaining educational and occupational outcomes for this group.

\section{A Portrait of Vietnamese Americans}

\section{Demographics}

The ancestral home of Vietnamese Americans is a region in Southeast Asia known as IndochinaVietnam, Cambodia, and Laos - the three countries that were affected by the Vietnam War, are parts of that area. According to the U.S. Census Bureau (2017), around 1.8 million individuals identify as Vietnamese only in the United States, making up about $10 \%$ of the Asian American population. Compared with 2010 Census figures, when Vietnamese Americans (alone or in combination with other ethnicities) numbered around 1.7 million individuals, this represents an increase of about $17 \%$ (the increase is $11 \%$ if only those identifying solely as Vietnamese are included). Overall, therefore, Vietnamese Americans have shown substantial growth within a seven-year timeframe. According to Kula and Paik (2016), the Vietnamese population growth has occurred due to births as well as continued immigration from Vietnam. In general, Vietnamese reside near metropolitan coastal areas in the United States, such as California, Washington, Texas, 
Virginia, and Florida. More Vietnamese live in California than any other state; approximately 36\% of their population resides there, and their second-largest population is in Texas (U.S. Census Bureau, 2017).

\section{Culture}

Vietnamese culture is generally collectivist, with a strong influence from Confucianism and Mahayana Buddhism (Huang \& Chang, 2017). Since the arrival of French Christian missionaries in feudal Vietnam, there has been a sizable population of Catholic Vietnamese; many of the first wave of Vietnamese immigrants who fled to the United States as refugees after the Fall of Saigon were from this group (Takaki, 1998). As such, the religious background of these immigrants is more diverse than that of other Southeast Asian Americans like Hmong or Cambodians (Moua \& Lamborn, 2010). Regardless of religious background, Vietnamese children are taught to respect the elderly and preserve family honor and integrity through a strong work ethic and academic excellence (Mestechkina et al., 2014). According to Caplan et al. (1991), the relative educational success of Vietnamese Americans can partially be explained by the transmission of these traditional cultural principles throughout generations instead of fully embracing the new American social customs. In other words, the top-performing Vietnamese youths are often those who adhere to traditional values and do not become too assimilated to the dominant American culture, which might include changing values, social behavior, and/or dietary preferences to those commonly found in the United States (Anderson et al., 1993; Fu \& VanLandingham, 2012). Such an assessment starkly contrasts with the idea that acculturation is the ideal approach for achieving prosperity in U.S. society (Zhou \& Bankston, 1998).

Like most Asian communities, Vietnamese Americans underline education as a pathway for moving upward in society (Robbins, 2004). Vietnamese parents frequently emphasize such beliefs with the hope that their children will internalize the traditional values and norms that will allow them to succeed academically in the future (Ngo \& Lee, 2007). As such, schooling is an investment for a brighter future, which explains the level of involvement from Vietnamese parents in their children's learning (Kibria, 1993; McBrien, 2011). Hence, family is a significant force behind the educational success of many Vietnamese Americans (Hung \& Haines, 1996; Phan, 2004). Vietnamese children are also expected to take on household responsibilities such as doing chores and aiding their younger siblings with homework, which can serve as a foundation for a good work ethic in the future (Caplan et al., 1991; Centrie, 2000).

Success in education is often considered an essential duty for children in Vietnamese households. Grades and other school affairs are frequently the topics of discussion during dinners or family gatherings (Rutledge, 1992). High expectations in terms of academic achievement are not confined within families, but also extend to the broader ethnic community (Centrie, 2000; Kibria, 1993). Older members may intervene when a child expresses their unwillingness to study and remind them about the sacrifice and struggles that their parents had to endure coming to the United States (Conchas, 2006; Rutledge, 1992).

However, specific cultural values may hinder the academic potential of some Vietnamese women (Conchas, 2006; Ngo \& Lee, 2007). Researchers have noted that some parents may fear that if their daughters become too educated, they might have a difficult time finding spouses and, subsequently, building families (Pataray-Ching et al., 2006). Additionally, Vietnamese boys often 
receive more support from their families and communities in terms of academics (Robbins, 2004); this, in turn, creates higher expectations for male students and may encourage them to study harder lest they face embarrassment for falling behind.

\section{Education}

Vietnamese came with both higher and lower educational attainment (Bankston et al., 1997). Today, according to the U.S. Census Bureau (2017), 25\% (approximately 543,000) have below a high school diploma, while $21 \%$ earned a high school diploma but have no college experience. In terms of higher education experience, there were about $22 \%$ of Vietnamese with some college experience and $20 \%$ with a college degree, while about $9.5 \%$ of the Vietnamese population held advanced graduate degrees. From 2010 to 2017, the number of Vietnamese Americans holding advanced degrees has increased by $4 \%$. Overall, the educational attainment of the Vietnamese American population is lower than the total Asian American population but still higher than other Southeast Asian groups (Niedzwiecki \& Duong, 2004). Educational attainment is also trending upward, with each generation more likely to attain higher degrees and/or qualifications overall than the generation prior. Some researchers have noted, however, that there is a subset of Vietnamese youth who exhibit lower attainment (Bui, 2018). Lee (2015) noted that this bifurcation is reflected in a characterization of Southeast Asian students as either high achievers or delinquents. Thus, though Vietnamese Americans are overall characterized as high achievers, particularly in comparison with other Southeast Asian groups (Lee et al., 2017; Zhou \& Lee, 2017), Vietnamese Americans have some mixed achievement and attainment outcomes.

In terms of occupational trends, Vietnamese Americans occupy a mix of working-class and professional industries (Niedzwiecki \& Duong, 2004). In 2017, the U.S. Census Bureau reported that among major occupations, Vietnamese were most likely to work in management, business, science, and the arts, (34.5\%) and as well as in service industries (29.3\%). A fair amount worked in sales and office occupations $(16.8 \%)$ and in production, transportation, and material moving $(14.6 \%)$. They were least likely to work in natural resources, construction, and maintenance occupations (4.8\%). About $10.7 \%$ of employed Vietnamese workers identify as self-employed, indicating a high degree of entrepreneurship (Le, 2019).

\section{The Immigration History of Vietnamese Americans}

While Asian immigrants have been immigrating to the United States since the 1800s, the Vietnamese presence was not prominent until the 1970s. According to Takaki (1998), there were just 603 South Vietnamese living in the United States in 1964, comprised of students, professionals, and political ambassadors. While early Asian immigrants came to the United States mostly for economic reasons, the Vietnamese were forced to relocate their lives to the United States due to the aftermath of the Vietnam War. The first wave of Vietnamese were not immigrants by choice, but rather by necessity, as refugees.

The French government colonized Vietnam in the late 1800s for about six decades (Huong \& Fry, 2004). Under the leadership of Ho Chi Minh, the Viet Minh fought the French in a bid to gain Vietnam's independence. In 1956, in Geneva, the French and the Viet Minh signed an

agreement to cease fire and temporarily created a line of demarcation at the seventeenth parallel (latitude 17 degrees North), which consequently divided the country into two sections, the North 
and South (Hall, 2000). In 1957, a civil war broke out in Vietnam, with the North led by Ho Chi Minh who was supported by Communist China and the Soviet Union, and the South headed by Ngo Dinh Diem who gained U.S. support. Over time, the U.S. involvement grew in the civil conflict through the presidencies of Kennedy, Johnson, and Nixon. On April 30th, 1975, the Vietnam War ended with the capture of Saigon by the Northern Vietnamese army. South Vietnam was forced to surrender, and the United States withdrew its forces.

\section{First Wave}

A week before the Fall of Saigon, the United States began to evacuate American and Vietnamese soldiers (Takaki, 1998); 10,000 to 15,000 Vietnamese people were initially evacuated from Vietnam before April 30th. Most of these individuals were military personnel from the Army of the Republic of Vietnam and their families (Lipman, 2014; Rumbaut, 2006). These individuals did not have any other choice but to migrate to the United States or face dire consequences under the new regime. In the last days of April, 86,000 additional Vietnamese were airlifted by American helicopters. Thousands of men, women, children fled to the American Embassy, airports, and various barges to escape persecution.

Approximately 130,000 Vietnamese refugees were given asylum in the United States in 1975 (Takaki, 1998). Upon arrival to the United States, the U.S. government placed over 100,000 refugees in four camps located in U.S. military bases: Camp Pendleton, California; Eglin Air Force Base, Florida; Fort Indiantown Gap, Pennsylvania; and Fort Chaffee, Arkansas (Lipman, 2014; Rumbaut, 1996). Fort Chaffee held 24,000 Vietnamese at any single point in time, and over 50,000 refugees were processed there in 1975, making it the largest refugee camp in the United States (Lipman, 2014; Takaki, 1998). The U.S. policy intended to send the refugees to live under sponsorships throughout the nation, in order to encourage rapid assimilation and lessen the burden on any one community. However, in practice, some states, like California, ended with a disproportionate number of refugees (Rumbaut, 1996). Additionally, many refugees left the communities where they were placed and resettled near kin or other co-ethnics they had met in the camps (Desbarats, 1985; Kula \& Paik, 2016). By 1980, 75\% of the refugee population resided in four states (Desbarats, 1985); by 2000, 40\% of Vietnamese $(440,000)$ resided in California alone (Ling et al., 2015). These large numbers of "secondary migrations" led to the establishment of ethnic enclaves with a high concentration of Vietnamese immigrants. In the Western states, "Little Saigons" began to form (Dorais, 2010; Liu \& Geron, 2008).

This first wave of Vietnamese refugees (1975-1978) were generally educated, had lived in the cities, and had achieved some financial stability prior to their arrival, though they had to abandon any wealth as they fled Vietnam (Rutledge, 1992). About 20\% had a college degree, and about $38 \%$ had completed high school (Kelly, 1986), while almost 65\% knew how to speak English well or with some fluency (Takaki, 1998). Due to French colonization and American involvement in South Vietnam, the Vietnamese in the first wave were somewhat familiar with Western culture and values. About $50 \%$ of the refugee population were Christians, primarily Catholics, and half were women (Takaki, 1998).

The refugees, as they settled in the United States, encountered a country that had experienced significant political, economic, and social upheaval. The Watergate scandal had forced the resignation of President Nixon in 1974, less than one year prior to the fall of Saigon. Additionally, clashes related to the Vietnam War had rocked the nation for over a decade, as more and more Americans came to oppose U.S. involvement prior to the fall of Saigon (Harrison, 1993). 


\section{Second Wave}

Between 1979 through 1982, the second wave of refugees from Vietnam began to arrive. After the establishment of a unified Vietnam under the Communist Party, there was a mass exodus to temporary encampments, mostly in Thailand, which eventually provided passage as refugees to the United States, especially among Vietnamese with Chinese heritage (Freeman, 1995; Rumbaut, 1989). Additionally, in the early 1980s, the Sino-Vietnam War erupted, and continuous restrictive trade with countries created economic hardships in Vietnam (Dosch \& Vuving, 2008). These second-wave refugees who fled persecution or economic disaster tended to come from rural areas, and were mostly comprised of farmers with little to no educational background (Rumbaut, 2006).

Throughout the War, as well as in the years waiting in camps, the second wave of Vietnamese had experienced personal trauma and family separation. The trauma of their escape from Vietnam, leaving their loved ones behind, uncertainty of their future, language limitations, downward mobility, and cultural clashes between Vietnamese and American ways of life, had grave psychosocial effects on many of the refugees (Bach \& Carroll-Seguin, 1986; Montero \& Dieppa, 1982; Silverman, 2010). Additionally, the United States government continued to intentionally place the Vietnamese refugees across all states (Kula \& Paik, 2016; Montero \& Dieppa, 1982; Takaki, 1998). Consequently, the dispersion of refugees denied access to ethnic enclaves that usually provide economic opportunities and support in acclimating to a new environment (Kelly, 1986; Montero \& Dieppa, 1982; Silverman, 2010).

These refugees were relatively uneducated and unskilled with limited English skills and no training in industrial jobs in the United States at the time (Rumbaut, 2006; Rutledge, 1992). As such, these barriers to prosperity were much more challenging to overcome than those experienced by the first wave.

\section{Third Wave}

The third wave arrived in smaller numbers, in comparison to the first and second waves, starting in the mid-1980s through the 1990s (Rumbaut, 2006). New policies and programs, such as the Amerasian Homecoming Act, Orderly Departure Program, and the Humanitarian Operations, aimed to bring and support the remaining victims of the Vietnam War to America. The Amerasian Homecoming Act was issued in 1982 for the reunification of Vietnamese children, as well as Korean, Laotian, Cambodian, and Thai, to their American fathers in the United States (Chuong \& Van, 1994). This legislative act did not permit mothers nor half-siblings of the Amerasians to immigrate. The Orderly Departure Program offered education and employment programs to refugees. Both the Orderly Departure Program and the Humanitarian Operation were part of the sponsorship program, which focused on the family reunification and resettlement process (including job employment, housing, accessing medical care, and adjustment to American life). While a high number of the third wave were classified as refugees, over time, more and more of the new arrivals came as regular immigrants. The level of education was limited for the third wave refugees, and they tended to have inadequate job skills to succeed in U.S. industries (Rumbaut, 2006). This refugee group was able to assimilate directly into well-established Vietnamese ethnic enclaves, which provided immediate support and survival. 


\section{New Millennium}

From 2000 to the present day, the new millennium shows a steady growth pattern of Vietnamese immigrants. Comparing the 2010 and 2017 foreign-born U.S. Census data, the Vietnamese foreignborn population has increased by $12 \%(154,076)$ over seven years. Vietnamese immigrants are now the sixth-largest foreign-born group in the country (U.S. Census Bureau, 2017). Vietnamese immigrants continue to reside in California (39\%), Texas (13\%), as well as Washington and Florida (4\%). One-third of Vietnamese reside in metropolitan areas like Los Angeles (19\%), San Jose (8\%), and Houston, at 6\% (Batalova \& Alperin, 2018). About 66\% have limited English proficiency (U.S. Census Bureau, 2017).

\section{Modes of Incorporation for Vietnamese Americans}

Factors that impacted the lives of Vietnamese Americans include government policy, societal receptivity, and co-ethnic community; additionally, location, class status, occupation, and English language ability also offered either benefits or obstacles to acculturation.

\section{Government Policy}

The United States' involvement in the Vietnam War resulted in receptive government policies for Vietnamese refugees. After the Geneva Convention of 1954, which divided Vietnam into two partitions - North and South, the United States subtly supported the Republic of Vietnam, in order to oppose the expansion of communism (Hagopian, 2009). However, it was not until early 1960 that the United States began to be heavily involved in the Vietnam War under presidents Kennedy and Johnson. After the fall of Saigon in 1975, the United States retired its forces. As a result, the United States aided the evacuation of over 130,000 refugees.

Due to the U.S. involvement in Vietnam, President Gerald Ford issued the Indochina Migration and Refugee Assistance Act (IMRA) on May 13, 1975 (Silverman, 2010). Under this act, Vietnamese refugees, as well as other Southeast Asian groups affected by the War, received assistance from the government to resettle in the United States. The program established relocation agencies that would seek sponsors, such as churches, American families, former refugees, and businesses, to help in the resettlement process, especially financially (Norman, 1983; Kelly, 1986). The refugees were given special legal status, aided in relocation, and paired with sponsors to help with job placement and living expenses (Hing, 1997; Kelly, 1986; Valverde, 1992). A supplemental program called the Indochina Refugee Children Assistance Act of 1976 was also funded under the IMRA. It provided educational financial assistance for children. From 1975 to 1978, the United States spent about 1 billion dollars implementing the IMRA (Norman, 1983). While the IMRA was scheduled to expire in 1977, it continued until 1980, when it was replaced by the Refugee Act of 1980 (Norman, 1983). This legislation continued to accept and assist refugees throughout the United States by providing resettlement services such as job training, employment counseling, daycare, English language instruction, physical and mental health care, social services, and special educational projects for refugee children (Norman, 1983). States were mandated to provide a plan for resettlement services and to assign a coordinator of refugee affairs. 
In 1979, the United Nations High Commissioner for Refugees along with the Socialist Republic of Vietnam established the Orderly Departure Program, which allowed legal immigration from Vietnam. This program assisted family members of Vietnamese American refugees, who lived in Vietnam as well as in refugee camps around the world, safe passage to the United States (Kumin, 2008). Over a million people emigrated from Vietnam through the Orderly Departure Program (Kumin, 2008).

Additionally, the war left Vietnam with approximately 30,000 Amerasian children, born to Vietnamese women but fathered by American men, mostly soldiers (Valverde, 1992). These Amerasian children suffered rejection from both parents' countries. In Vietnam, the children's fatherless status marginalized them in society, and they were persecuted due to their parental lineage to America (Valverde, 1992). In response, the United States issued the Amerasian Act of 1982. The law provided Amerasians from Vietnam, Laos, Korea, Cambodia, and Thailand, who were fathered by U.S. servicemen or citizens, legal entrance to the United States. This act did not apply to their mothers nor relatives. However, in 1987, the Amerasian Act was expanded to allow Amerasian children to enter the United States with their immediate families (Kula \& Paik, 2016). Arrivals via the Amerasian Acts of 1982 and 1987 were given "immigrant" rather than "refugee" status, thereby denying them all the services and benefits offered to refugees (Valverde, 1992). However, on October 28, 1987, the Amerasian Homecoming Act gave Amerasians born between 1962 and 1977 immigration status with refugee benefits and services. Amerasians applicants had to prove American paternity through documentation, such as birth certificates, marriage licenses, and letters or photos of the father (Valverde, 1992). About 83,000 immigrants entered the United States by 1993 under this law (Hidalgo \& Bankston, 2008).

\section{Societal Reception}

Though the government policies were receptive to Vietnamese immigration, societal reception was prejudiced overall for the new arrivals. The Vietnam War ignited fiery debates in the United States in the 1960s (Hagopian, 2009; Schreiber, 1973). Some Americans saw the war as a fight against communism (Brown, 1981), while others viewed it as a tragic loss of American lives (Hagopian, 2009). With such division and hostility, Vietnamese refugees were stuck in the middle of the controversy. Transitioning to a new location with a different culture and language gave rise to high levels of discrimination (Kim et al., 2019). According to a survey in 1992, 70\% of Southeast Asian refugee children reported that they had experienced discrimination regarding their race (Zhou \& Xiong, 2005). Like many Asian immigrant groups, the Vietnamese endured racial slurs and namecalling (Takaki, 1998). Limited English proficiency, culture, and low socioeconomic status were other areas of discrimination. Vietnamese were continuously treated as second-rate citizens (Tseng, 2007). Many men faced low wage paying jobs or unemployment (Rutledge, 1992). In Texas, on the Gulf Coast, Vietnamese fishers were threatened, and some killed, by the Ku Klux Klan because the refugees were perceived as a threat to their job market (Takaki, 1998). During this time, unemployment was high, at 9\%, and many Americans feared that refugees would take over the few jobs available (Montero \& Dieppa, 1982).

The United States, along with other countries, assumed the historical responsibility of Southeast Asian refugees by providing refugee programs (Tseng, 2007). Volunteer agencies, known as VolAgs, provided services, such as housing placement, orientation, and sponsorship to refugees. These refugee assistance programs relied on U.S. citizens to volunteer. However, as more and more Vietnamese entered the United States in the 1980s, the American people began to feel 
"compassion fatigue," an attitude of active hostility that derived from providing resources to refugees in need over a long period (LeMaster \& Zall, 1983). This was complicated by economic crises in the late 1970s when the United States entered a recession while continuing to fund refugee programs at the cost of over a billion dollars. Some agencies encouraged refugees to seek and remain on welfare for the maintenance of their services (LeMaster \& Zall, 1983).

\section{Co-ethnic Community}

While there were a small number of Vietnamese residing in the United States before the conclusion of the Vietnam War, it was not until 1975 that there were massive upticks in immigration from Vietnam after the collapse of the Republic of Vietnam (Rumbaut, 2006; Takaki, 1998). This initial wave of refugees in the United States was scattered in multiple locations by the government in order to accelerate integration in American society and to prevent few states from taking on the massive fiscal burden (Desbarats, 1985). Specifically, most of these Vietnamese were spread out in one of the four federally run transition camps (Montero \& Dieppa, 1982): Pendleton (California), Fort Chaffee (Arkansas), Eglin (Florida), and Fort Indiantown Gap (Pennsylvania). During their time there, Vietnamese refugees formed personal relationships that served as a basis for their future ethnic network. After receiving basic training for integrating into American society at these camps, the Vietnamese population was relocated to various locations with the help of VolAgs, which included non-profit organizations, churches, and other such groups. The result was a high level of dispersion among the first-wave Vietnamese immigrants (Desbarats, 1985), with little chance of forming ethnic communities had the refugees maintained their initial settlements in the United States.

However, a combination of the desire to be close to those with the same cultural bond and more significant social incentives from individual states like California resulted in a secondary migration, driving many Vietnamese to relocate and concentrate in specific areas, creating the foundation for co-ethnic communities (Paik et al., 2014; Portes \& Zhou, 1993; Rumbaut, 2006). This was partially due to the personal networks formed during the time at the government camps.

The first wave of Vietnamese immigrants also had certain advantages that helped to accelerate the formation of ethnic communities once they concentrated in certain areas. These included a relatively higher level of education and business or entrepreneurial backgrounds, as well as a certain degree of proficiency in English (Desbarats, 1985; Kelly, 1986). The majority of these immigrants came from more developed cities, especially Saigon, in Southern Vietnam, many of whom had owned business or possessed other professional skills. The higher frequency of interaction with Americans, such as U.S. soldiers or diplomats, meant more familiarity with U.S. bureaucracy and, significantly, the English language. All in all, even with little financial capital, these experiences translated to a relatively highly prepared immigrant population that could navigate U.S. institutions and lay the foundation for strong co-ethnic communities (Kula \& Paik, 2016).

Due to the social and economic infrastructure established by the more educated and experienced first-wave Vietnamese Americans, immigrants from second and third waves had less difficulty settling down in the new country (Kim, 2002; Kula \& Paik, 2016). While the later waves were generally not as educated or having other forms of social and professional capitals, they brought with them a sizable amount of human capital that helped strengthen the new formed ethnic 
enclaves and ensure the possibility of future Vietnamese American populations (Rumbaut, 2006). Consequently, Vietnamese Americans, as a whole, have a relatively strong co-ethnic community in the United States which benefited later waves (Kelly, 1986; Portes \& Rumbaut, 2014).

\section{Other Barriers and Opportunities}

Like any immigrant group, Vietnamese Americans came with a unique set of resources but also faced unique challenges. Many refugees from the first wave and a few from the second possessed advanced education and professional training. Nonetheless, like many Asian groups before them, most Vietnamese immigrants had to accept downgrades in their social and professional status when first arriving in the United States, even though they had relevant, but not recognized, degrees and credentials (Anderson, 2005; Bach \& Carroll-Seguin, 1986; Takaki, 1998). The situation was worse for most of the second- and third-wave Vietnamese immigrants since they had little education or specialized skills, forcing them to settle for manual labor jobs at minimum wage (Rumbaut, 2006). However, the sizable portion of Chinese Vietnamese within the broader Vietnamese American community was able to secure additional financial capital from Chinese investors abroad, strengthening businesses in these ethnic enclaves (Aguilar-San Juan, 2009).

In terms of settlement locations, they were able to put down roots in different parts of the country after relocation by the government (Desbarats, 1985; Kelly, 1986), unlike pre-1965 Asian immigrants who were mostly restricted to Hawaii and the western coast of the United States. They ended up establishing ethnic towns close to metropolitan areas in coastal states, most notably California (U.S. Census Bureau, 2017). Unfortunately, these communities were often adjacent to high-poverty areas with low-performing schools, negatively impacting some Vietnamese American children (Hidalgo \& Bankston, 2008; Zhou \& Xiong, 2005). Even with the collective social and material resources from the Vietnamese community, the effects of living in such areas could still be seen in the subsequent academic performance of the later Vietnamese American population, particularly for those who were not as engaged in the co-ethnic community (Hidalgo \& Bankston, 2008; Paik et al., 2014).

Other forms of capital were also eroded over time as less educated waves of Vietnamese immigrants came and outnumbered the more English fluent refugees from the first wave (Kula \& Paik, 2016). Immigrants from later waves who had never been through government-run camps in the United States did not have that avenue for learning English and understanding the American society, despite the basic skills taught at these camps. The concentration of many individuals with a shared language and inadequate schooling may have lessened the will and need to learn English, possibly contributing to the fact that many parents of second-generation Vietnamese Americans were still not able to speak English well into the 2000s, as reported by their children (Niedzwiecki \& Duong, 2004).

Lastly, many Vietnamese refugees, as well as other Southeast Asian groups, were involuntary immigrants fleeing from their homelands, unlike earlier waves of Asians (Takaki, 1998). Along the way, family members were separated, and many never had the chance to see each other again; the experience was particularly damaging to children (Harding \& Looney, 1977). This had considerable impacts on refugees' psychological well-being with long-term consequences, potentially affecting their ability to integrate into American society or assist their children in education (Kula \& Paik, 2016). While such trauma was noted while the refugees were being processed in federal camps, no serious attempts from the government were made subsequently to 
address the matter (Montero \& Dieppa, 1982). Given the severity of such an issue, the psychological health of Vietnamese immigrants is an essential factor in understanding the trend in the academic performance of this population.

\section{Linking the Past to Current Educational Outcomes}

The educational experiences of Vietnamese in the United States are influenced by American government policies, societal reception, co-ethnic communities, and other barriers and opportunities, such as time of arrival, location, and English proficiency. The combination of these factors can be linked to a mixed level of academic attainment for Vietnamese Americans.

An examination of Vietnamese immigrants to the United States reveals that receptive government policies, co-ethnic enclaves, location, time, and some English proficiency gave significant advantages for survival in a new setting. Through favorable government policies, Vietnamese refugees were able to survive financially due to government assistance. These resources granted Vietnamese the ability to focus on other pressing matters like education and upward mobility. By being placed at military camps for a limited time, Vietnamese immigrants were allowed to establish social networks, building social capital which would later help establish co-ethnic communities for future waves of immigration, a crucial factor for academic advancement.

Government relocation agencies were established to aid in the resettlement process by seeking sponsorship from churches, businesses, and American families to assist in job placement and living expenses. These resources and personal connections established stability for these families. Job placement granted Vietnamese immigrants valuable experience in a new field, consequently expanding their education and social network. Employment is a crucial factor to rise against poverty. Supplemental programs, such as the Indochina Refugee Children Assistance Act of 1976, provided educational and financial assistance for children. This act specifically targeted the educational needs of Vietnamese students to prepare institutions for their academic advancement. Refugees were given legal status, which provided more significant opportunities for upward mobility in terms of educational attainment. Many of the first waves of refugees were educated and had some English proficiency, which helped them maneuver through the American and educational systems. This wave of refugees established the foundation for future Vietnamese immigrants and Vietnamese Americans.

The experiences of second and third wave of Vietnamese refugees reveal that receptive government policies alone are not enough. While government support and resettlement assistance were critical for their survival, many of the second and third waves of Vietnamese refugees arrived with limited language and job skills. Limited English proficiency and low socioeconomic status negatively affected their academic advancement in an English-only educational system. In response, resettlement services provided English instruction and social services (Norman, 1983), with the intent to equip the Vietnamese community with the ability to communicate in their new setting, build bridges with the U.S. citizens, and open employment opportunities from mainstream society. Not only were Vietnamese immigrants from the second and third wave limited in English proficiency, but they were also less educated and had fewer professional skills than those from the first wave. As a result, parents from these waves may not have had adequate resources nor the English ability to assist their children's education both inside and outside of school. 
While receptive government policies fostered an initial receptive social response of compassion toward Vietnamese refugees through their experiences with VolAgs, as time progressed, Vietnamese refugees were overall negatively received by mainstream society. As government policies intensified their financial support toward refugees, mainstream society viewed them as an economic threat and burden. The American people began to feel "compassion fatigue" since resources were provided for an extended period (LeMaster \& Zall, 1983). High rates of unemployment stoked fears that refugees would exacerbate job insecurity (Montero \& Dieppa, 1982); this limited occupational opportunities in mainstream employment. Consequently, Vietnamese immigrants often depended upon their co-ethnic communities for employment. Within these communities, Vietnamese Americans were afforded security against the initial hostility from society while also enjoying friendlier businesses and services along with the prospect of employment for new settlers with low professional experience. Because of such collective support, older Vietnamese Americans could focus on providing resources for their children, allowing them to excel academically.

The United States government made a great effort to place Vietnamese refugees across all states to force rapid assimilation and to avoid placing a fiscal burden on the states and surrounding communities (Kula \& Paik, 2016; Montero \& Dieppa, 1982; Takaki, 1998). Unfortunately, the dispersion of refugees denied them initial access to ethnic enclaves that usually provide economic opportunities, support in acclimating to a new environment, and access to educational advancement (Kelly, 1986; Montero \& Dieppa, 1982; Silverman, 2010), forcing them to either acclimate where they were placed to engage in a costly secondary migration to access their coethnic communities. Socially, many Vietnamese immigrants, especially the newly arrived, were wary about venturing outside their ethnic islands; as such, parents, while stressing the importance of academic success, also rarely participated in school events (Davis \& McDaid, 1992). This reality may have added to the struggle of Vietnamese American youth who were already trying to adjust to the new social setting. Many Vietnamese ethnic enclaves are located in the desirable metropolitan and coastal areas; at the same time, these communities are also adjacent to socially and financially disadvantaged neighborhoods. As such, Vietnamese American youth who stay engaged in their local co-ethnic communities can draw from its cultural resources, while those who assimilate into mainstream American culture may adopt values counter to academic success (Bankston \& Zhou, 1997). Along with the other factors in the model, these forces together may explain some of the mixed academic achievement seen in the Vietnamese American community.

The strong co-ethnic communities of the Vietnamese Americans, as well as their specific placements, have been mostly beneficial for the subsequent academic performance of the population. Ethnic enclaves certainly provide a considerable amount of assistance to new Vietnamese immigrants as well as those of second and later generations.

For most immigrants, the transition to the United States, encountering a new location with a different culture and language, was experienced in tandem with high levels of discrimination (Kim et al., 2019). Racial discrimination affects a person's health, poses barriers to upward mobility in employment, and limits an individual's accumulation of wealth (Blank et al., 2004). Children reported that they had experienced discrimination concerning their race (Zhou \& Xiong, 2005), which undoubtedly included their school environment. Blank et al. (2004) noted that discrimination in primary education can negatively affect the outcomes of secondary school and college access. Every single act of discrimination builds barriers and oppresses. Vietnamese were continuously treated as second-rate citizens (Tseng, 2007). 
Other factors have also either directly or indirectly contributed to the mixed education performance of the Vietnamese. One prominent hurdle was the fact that they were less familiar with American institutions and social structure, creating more burden for Vietnamese American youth in navigating the education pipeline to higher education. Another barrier involved the longterm psychological effects of traumas many Vietnamese immigrants had to endure during their journey coming to the United States. Without any recourse to remedy these issues, it might be difficult for many Vietnamese Americans to reach a high level of academic performance.

In terms of positive forces, the religious traditions of the Vietnamese American community, including Catholicism, Confucianism, or Mahayana Buddhism, all emphasize respect for elders and preserving family honor through, in part, academic excellence. Those who internalize these tenets may become more resilient in school and beyond - another way in which engagement with the co-ethnic community served as a positive factor toward high achievement.

Overall, the relatively high education attainment of Vietnamese Americans can be attributed to the favorable government policies and their strong co-ethnic communities. However, prejudice from societies and other obstacles that emerged from migrating to the United States may have impeded the economic or academic potential of this particular population.

\section{Conclusion and Implications}

Given the diversity within the Asian American community, it is important to gain more understanding of the past and present circumstances of each of these groups. This is especially important for the Vietnamese population due to their recent but turbulent immigration experiences that can be linked to mixed academic performance. This paper systematically and comprehensively brought together the extant research in providing an application of Paik et al.'s (2014) model, which demonstrates the importance of the history and context of Vietnamese immigration and incorporation in terms of their influence on current educational and occupational outcomes for this group. As the existing research is relatively sparse in comparison to other minority groups, more research on Vietnamese Americans is needed to inform key stakeholders on how to best support their students and communities at different levels. Specifically, research on best practices for educating Vietnamese American students represents an area of research that may further assist practitioners as well as policymakers in ensuring that such students are well served by U.S. educational institutions.

Overall, favorable government policy and a strong co-ethnic community have helped Vietnamese Americans in becoming an integral part of U.S. society. Therefore, it is essential that government policies continue to support the needs of this population, as well as other immigrant groups. It is imperative that more research be conducted on the co-ethnic enclaves, especially focused on how Vietnamese Americans draw from these resources to aid in increased educational outcomes. However, it is important to note that these factors alone may not be enough to overcome the challenges posed by prejudice, combined with the lack of education, language, and job skills from the later waves of Vietnamese immigrants.

As such, specific solutions are needed to tackle the obstacles preventing Vietnamese American students from excelling. While discrimination has perhaps become less intense in today's society, Vietnamese Americans are facing a different form of social pressure: the model minority stereotype. Although a relatively large portion of Vietnamese students are doing well in school, educational practitioners must be aware that this is not the case for everyone. Thus, a fair 
expectation should be placed on Vietnamese Americans, meaning they should have the opportunity to get help in school when struggling. English language learning services and bilingual services can also provide tremendous help to Vietnamese speaking parents and elders in order to create bridges between school and home (Wong et al., 2011; Ying \& Han, 2008).

Programs that can address different psychological issues can improve the mental wellbeing of both Vietnamese students and their parents, allowing them to do better in school (Kim et al., 2019; Sangalang et al., 2017). After all, subsequent generations of Vietnamese Americans have become more westernized while still having to come to terms with their ethnic roots at home and the immediate community. Services that can help facilitate a discussion on the sense of belonging and the shift in culture for both students and parents may prevent a misunderstanding from the cultural clash at home and beyond. For those who have undergone traumatic experiences while migrating from Vietnam to the United States, appropriate therapy programs could aid these immigrants in their journey to reach normalcy in everyday life and give them the chance to further aid their children in doing well in schools.

To put any of these initiatives in motion, however, requires that government agencies and other stakeholders work closely with Vietnamese American communities to gain useful insights from their experiences here in the United States. Through such an attempt, the Vietnamese community will be more integrated and become further invaluable for the modern American society, unleashing its full potential.

\section{References}

Aguilar-San Juan, K. (2009). Little Saigons: Staying Vietnamese in America. University of Minnesota Press.

Anderson, J., Moeschberger, M., Chen, M. S., Kunn, P., Wewers, M. E., \& Guthrie, R. (1993). An acculturation scale for Southeast Asians. Social Psychiatry and Psychiatric Epidemiology, 28(3), 134-41. https://doi.org/10.1002/erv.678

Anderson, W. W. (2005). Between necessity and choice: Rhode Island Lao American women. In W. W. Anderson \& R. G. Lee (Eds.), Displacements and diasporas: Asians in the Americas (pp. 194-226). Rutgers University Press. https://doi.org/10.36019/9780813537511-012

Bach, R. L., \& Carroll-Seguin, R. (1986). Labor force participation, household composition and sponsorship among Southeast Asian refugees. International Migration Review, 20(2), 38404. https://doi.org/10.1177/019791838602000214

Bankston, C. L. III, \& Zhou, M. (1997). The social adjustment of Vietnamese American adolescents: Evidence for a segmented-assimilation approach. Social Science Quarterly, 78(2), 508-523. https://www.jstor.org/stable/42864351

Bankston, C. L. III, Caldas, S., \& Zhou, M. (1997). The academic achievement of Vietnamese American students: Ethnicity as social capital. Sociological Focus, 30(1), 1-16. https://doi.org/10.1080/00380237.1997.10570679

Batalova, J., \& Alperin, E. (2018). Immigrants in the U.S. states with the fastest-growing foreign-born populations. Migration Policy Institute. https://www.migrationpolicy.org/article/immigrants-usstates-fastest-growing-foreign-born-populations-2016

Blank, R., Dabady, M., \& Citro, C. (2004). Measuring racial discrimination. National Academies Press. https://doi.org/10.17226/10887

Brown, C. (1981). Casualty. W.W. Norton. 
Bui, L. (2018). Examining the achievement-delinquency relationship among Southeast Asian Americans. International Journal of Offender Therapy and Comparative Criminology, 62(6), 1556-1572. https://doi.org/10.1177/0306624X17699896

Caplan, N., Choy, M. H., \& Whitmore, J. K. (1991). Children of the boat people: A study of educational success. University of Michigan Press. https://doi.org/10.3998/mpub.12808

Centrie, C. (2000). Free spaces unbound: Families, community, and Vietnamese high school students' identities. In L. Weis \& M. Fine (Eds.), Construction sites: Excavating race, class, and gender among urban youth (pp. 65-83). Teachers College Press.

Chan, S. (1991). Asian Americans: An interpretive history. Twayne.

Chuong, C. H., \& Van, L. (1994). The Amerasians from Vietnam: A California study. Southeast Asia Community Resource Center. https://renincorp.org/other-publications/handbooks/ amerasn.pdf

Conchas, G. Q. (2006). The color of success: Race and high-achieving youth. Teachers College Press.

Davis, D. G., \& McDaid, J. L. (1992). Identifying second-language students' needs: A survey of Vietnamese high school students. Urban Education, 27(1), 32-40. https://doi.org/10.1177/0042085992027001004

David, M. L., Luke, D., Peggy, P. H., Thupten, T., Chia, S. H., \& Valerie, O. P. (2017). Academic needs and family factors in the education of Southeast Asian American students: Dismantling the model minority myth. Journal of Southeast Asian American Education and Advancement, 12(2). https://docs.lib.purdue.edu/jsaaea/vol12/iss2/2/

Desbarats, J. (1985). Indochinese resettlement in the United States. Annals of the Association of American Geographers, 75(4), 522-538. https://doi.org/10.1111/j.1467-8306.1985.tb00091.x

Dorais, L. (2010). Politics, kinship, and ancestors: Some diasporic dimensions of the Vietnamese experience in North America. Journal of Vietnamese Studies, 5(2), 91132. https://doi.org/10.1525/vs.2010.5.2.91

Dosch, J., \& Vuving, A. (2008). The impact of China on governance structures in Vietnam. Deutsches Institut für Entwicklungspolitik. https://www.diegdi.de/uploads/media/DP_14.2008.pdf

Freeman, J. M. (1995). Changing identities: Vietnamese Americans, 1975-1995. Pearson College Division.

Fu, H., \& VanLandingham, M. J. (2012). Disentangling the effects of migration, selection and acculturation on weight and body fat distribution: Results from a natural experiment involving Vietnamese Americans, returnees, and never-leavers. Journal of Immigrant and Minority Health, 14(5), 786-796. https://link.springer.com/article/10.1007/s10903-012$\underline{9595-5}$

Hagopian, P. (2009). The Vietnam War in American memory: Veterans, memorials, and the politics of healing (Culture, politics, and the cold war). University of Massachusetts Press. https://www.jstor.org/stable/j.ctt5vk0pt

Hall, R. A. (2000). Combat battalion: The Eighth Battalion in Vietnam. Allen \& Unwin.

Harding, R. K., \& Looney, J. G. (1977). Problems of Southeast Asian children in a refugee camp. American Journal of Psychiatry, 134(4), 407-411. https://doi.org/10.1176/ajp.134.4.407

Harrison, B.T. (1993). Roots of the anti-Vietnam war movement. Studies in Conflict \& Terrorism, 16(2), 99-111. https://doi.org/10.1080/10576109308435923

Hidalgo, D. A., \& Bankston III, C. L. (2008). Military brides and refugees: Vietnamese American wives and shifting links to the military, 1980-2000. International Migration, 46(2), 167185. https://doi.org/10.1111/j.1468-2435.2008.00448.x 
Hing, B. O. (1997). Immigration policy: Making and remaking Asian Pacific America. In D. Hamamato \& R. D. Torres (Eds.), New American destinies: A reader in contemporary Asian and Latino immigration (pp. 315-324). Routledge. https://doi.org/10.4324/9780203379561-27

Huang, M., \& Chang, S. (2017). Similarities and differences inEast Asian Confucian culture: A comparative analysis. Omnes: The Journal of Multicultural Society, 7(2), 1-40. http://doi.dx.org/10.15685/omnes.2017.01.7.2.1

Hung, N. M., \& Haines, D. W. (1996). Vietnamese. In D. W. Haines (Ed.), Refugees in America in the 1990s: A reference handbook (pp. 305-327). Greenwood.

Huong, P. L., \& Fry, G. W. (2004). Education and economic, political, and social change in Vietnam. Educational Research for Policy and Practice, 3(3), 199-222. https:/link.springer.com/article/10.1007/s10671-005$\underline{0678-0}$

Kagawa-Singer, M., Hune, S., \& Maramba, D. (2011). The importance of critically disaggregating data: The case of Southeast Asian American college students. AAPINexus: Policy, Practice and Community, 9(12), 127-133. https://www.academia.edu/download/33173254/nexus9_1_2_full.pdf\#page=142

Kelly, G. P. (1986). Coping with America: Refugees from Vietnam, Cambodia, and Laos in the 1970s and 1980s. The ANNALS of the American Academy of Political and Social Science, 487(1), 138-149. https://doi.org/10.1177/000271628648700s 1009

Kibria, N. (1993). Family tightrope: The changing lives of Vietnamese Americans. Princeton University Press. https://doi.org/10.1515/9781400820993

Kim, I., Keovisai, M., Kim, W., Richards-Desai, S., \& Yalim, A. (2019). Trauma, discrimination, and psychological distress across Vietnamese refugees and immigrants: A life course perspective. Community Mental Health Journal, 55(3), 385-393. https:/link.springer.com/article/10.1007/s10597$\underline{018-0268-2}$

Kim, R. (2002). Ethnic differences in academic achievement between Vietnamese and Cambodian children: Cultural and structural explanations. The Sociological Quarterly, 43(2), 213-235. https://doi.org/10.1111/j.1533-8525.2002.tb00047.x

Kula, S. M., \& Paik, S. J. (2016). A historical analysis of Southeast Asian refugee communities: Post-war acculturation and education in the U.S. Journal of Southeast Asian American Education and Advancement, 11(1), 1-28. http://doi.org/10.7771/2153-8999.1127

Kumin, J. (2008). Orderly departure from Vietnam: Cold war anomaly or humanitarian innovation? Refugee Survey Quarterly, 27(1), 104-117. https://doi.org/10.1093/rsq/hdn009

Le, C. N. (2019). "Asian small businesses.” Asian-nation: The landscape of Asian America. Asian Nation. https://www.asian-nation.org/small-business.shtml

Lee, D. M., Duesbery, L., Han, P. P., Tashi, T., Her, C. S., \& Ooka Pang, V. (2017). Academic needs and family factors in the education of Southeast Asian American students: Dismantling the model minority myth. Journal of Southeast Asian American Education and Advancement, 12(2), 1-31. https://doi.org/10.7771/2153-8999.1154

Lee, S. (2015). Unraveling the "model minority" stereotype: Listening to Asian American youth (2nd ed.). Teachers College Press.

LeMaster, R. J., \& Zall, B. (1983). Compassion fatigue: The expansion of refugee admissions to the United States. Boston College International and Comparative Law Review, 6(2), 447474. https:/heinonline.org/HOL/LandingPage?handle=hein.journals/bcic6\&div=20\&id=\&page=

Ling, H., \& Austin, A. (Eds). (2015). Asian American history and culture: An encyclopedia (Vol. 1-2). Routledge. https://doi.org/10.4324/9781315706306

Lipman, J. (2014). A refugee camp in America: Fort Chaffee and Vietnamese and Cuban refugees, 1975-1982. Journal of American Ethnic History, 33(2), 57-87. https://doi.org/10.5406/jamerethnhist.33.2.0057 
Liu, M., \& Geron, K. (2008). Changing neighborhood: Ethnic enclaves and the struggle for social justice. Social Justice, 35(2), 18-35. https://www.jstor.org/stable/29768486

McBrien, J. (2011). The importance of context: Vietnamese, Somali, and Iranian refugee mothers discuss their resettled lives and involvement in their children's schools. Compare: A Journal of Comparative and International Education, 41(1), 75-90. https://doi.org/10.1080/03057925.2010.523168

Mestechkina, T., Son, N., \& Shin, J. (2014). Parenting in Vietnam. In H. Selin (Ed.), Parenting across cultures: Childrearing, motherhood and fatherhood in non-western cultures (pp. 47-58). Springer. https://doi.org/10.1007/978-94-007-7503-9_5

Montero, D., \& Dieppa, I. (1982). Resettling Vietnamese refugees: The service agency's role. Social Work, 27(1), 74-82. https://doi.org/10.1093/sw/27.1.74

Moua, M. Y., \& Lamborn, S. D. (2010). Hmong American adolescents' perceptions of ethnic socialization practices. Journal of Adolescent Research, 25(3), 416-440. https://doi.org/10.1177/0743558410361369

Museus, S. (2013). Unpacking the complex and multifaceted nature of parental influences on Southeast Asian American college students' educational trajectories. Journal of Higher Education, 84(5), 708-738. https://doi.org/10.1080/00221546.2013.11777306

Ngo, B., \& Lee, S. J. (2007). Complicating the image of model minority success: A review of Southeast Asian American education. Review of Educational Research, 77(4), 415-453. https://doi.org/10.3102/0034654307309918

Niedzwiecki, M., \& Duong, T. C. (2004). Southeast Asian American statistical profile. Southeast Asia Resource Action Center (SEARAC). https://www.searac.org/wp-content/uploads/2018/04/Statistical-Profile2010.pdf

Norman, L. (1983). Refugee resettlement in the United States: Policy and problems. The Annals of the American Academy of Political and Social Science, 467(1), 172-186. https://doi.org/10.1177/0002716283467001013

Paik, S. J., Kula, S. M., Saito, L. E., Rahman, Z., \& Witenstein, M. A. (2014). Historical perspectives on diverse Asian American communities: Immigration, incorporation, and education. Teachers College Record, 116(8), 1-45. https://www.tcrecord.org/Content.asp?Contentld=17512

Paik, S. J., Rahman, Z., Kula, S. M., Saito, L. E., \& Witenstein, M. A. (2017). Diverse Asian American families and communities: Culture, structure, and education (Part 1: Why they differ). The School Community Journal, 27(2), 35-66. https:/www.adi.org/journal/2017fw/PaikEtAlPart1Fall2017.pdf

Pang, V. O., Han, P. P., \& Pang, J. M. (2011). Asian American and Pacific Islander students: Equity and the achievement gap. Educational Researcher, 40(8), 378-389. https://doi.org/10.3102/0013189X11424222

Pataray-Ching, J. (with Kitt-Hinrichs, B., \& Nguyen, V). (2006). Inquiring into a second language and the culture of school. Language Arts, 83(3), 248-257. https:/library.ncte.org/journals/la/issues/v83$\underline{3 / 4868}$

Phan, T. (2004). A qualitative study of Vietnamese parental involvement and their high academic achieving children. Journal of Authentic Learning, 1, 51-61. http://hdl.handle.net/1951/399

Poon, O., Squire, D., Kodama, C., Byrd, A., Chan, J., Manzano, L., Furr, S., \& Bishundat, D. (2016). A critical review of the model minority myth in selected literature on Asian Americans and Pacific Islanders in higher education. Review of Educational Research, 86(2), 469-502. https://doi.org/10.3102/0034654315612205

Portes, A., \& Rumbaut, R. G. (2014). Immigrant America: A portrait. University of California Press. https://doi.org/10.1525/9780520959156

Portes, A., \& Rumbaut, R. G. (2001). Legacies: The story of the immigrant second generation. University of California Press. 
Portes, A., \& Zhou, M. (1993). The new second generation: Segmented assimilation and its variants. Annals of the American Academy of Political and Social Science, 530(1), 74-96. https://doi.org/10.1177/0002716293530001006

Robbins, K. (2004). Struggling for equality/struggling for hierarchy: Gender dynamics in an English as an additional language classroom for adolescent Vietnamese refugees. Feminist Teacher, 15(1), 66-79. https://www.jstor.org/stable/40545907

Rumbaut, R. G. (1989). The structure of refuge: Southeast Asian refugees in the United States, 1975-1985. International Review of Comparative Public Policy, 1, 97-129. https://ssrn.com/abstract=1886685

Rumbaut, R.G. (1996). A legacy of war: Refugees from Vietnam, Laos, and Cambodia. In S. Pedraza \& R. G. Rumbaut (Eds.), Origins and destinies: Immigration, race, and ethnicity in America. Wadsworth Publishing Company. https://ssrn.com/abstract=2146972

Rumbaut, R. G. (2006). Vietnamese, Laotian, and Cambodian Americans. In P. G. Min (Ed.), Asian Americans: Contemporary Trends and Issues (2nd ed., pp. 262-289). Sage Publications.

Rutledge, P. J. (1992). The Vietnamese experience in America. Indiana University Press.

Sangalang, C. C., Jager, J., \& Harachi, T. W. (2017). Effects of maternal traumatic distress on family functioning and child mental health: An examination of Southeast Asian refugee families in the U.S. Social Science \& Medicine, 184, 178-186. https://doi.org/10.1016/j.socscimed.2017.04.032

Schreiber, E. (1973). Opposition to the Vietnam war among American university students and faculty. The British Journal of Sociology, 24(3), 288-302. https://doi.org/10.2307/588233

Shih, K., Chang, T., \& Chen, S. (2019). Impacts of the model minority myth on Asian American individuals and families: Social justice and critical race feminist perspectives. Journal of Family Theory \& Review, 11(3), 412-428. https://doi.org/10.1111/jftr.12342

Silverman, E. (2010). Indochina legacy: The refugee act of 1980. Publius, 10(1), 27-41. https:/www.jstor.org/stable/3329800

Takaki, R. (1998). Strangers from a different shore: A history of Asian Americans. First Back Bay.

Takei, I., Sakamoto, A., \& Kim, C. H. (2013). The socioeconomic attainments of non-immigrant Cambodian, Filipino, Hmong, Laotian, Thai, and Vietnamese Americans. Race and Social Problems, 5(3), 198-212. https://ink.springer.com/article/10.1007\%2Fs12552-013-9089-7

Tseng, W. (2007). Immigrant community services in Chinese and Vietnamese enclaves (New Americans). LFB Scholarly Pub.

U.S. Census Bureau. (2017). Selected population profile in the United States, 2017 American Community Survey 1year estimates. https://www.census.gov/programs-surveys/acs/technical-documentation/table-and-geographychanges/2017/1-year.html

Valverde, K. C. (1992). From dust to gold: The Vietnamese Amerasian experience. In M. P. P. Root (Ed). Racially mixed people in America (pp. 144-161). Sage Publications.

Wong, Y. J., Tran, K. K., Schwing, A. E., Cao, L. H., Ho, P. P. H., \& Nguyen, Q. T. (2011). Vietnamese American immigrant parents: A pilot parenting intervention. The Family Journal, 19(3), 314-321. https://doi.org/10.1177/1066480711406697

Ying, Y. W., \& Han, M. (2008). Parental contributions to Southeast Asian American adolescents' well-being. Youth \& Society, 40(2), 289-306. https://doi.org/10.1177/0044118X08315506

Zhou, M., \& Bankston, C. L. III (1998). Growing up American: How Vietnamese children adapt to life in the United States. Russell Sage. https://www.jstor.org/stable/10.7758/9781610445689

Zhou, M., \& Lee, J. (2017). Hyper-selectivity and the remaking of culture: Understanding the Asian American achievement paradox. Asian American Journal of Psychology, 8(1), 7-15. https://doi.org/10.1037/aap0000069 
Zhou, M., \& Xiong, Y. S. (2005). The multifaceted American experiences of the children of Asian immigrants: Lessons for segmented assimilation. Ethnic and Racial Studies, 28(6), 11191152. https://doi.org/10.1080/01419870500224455

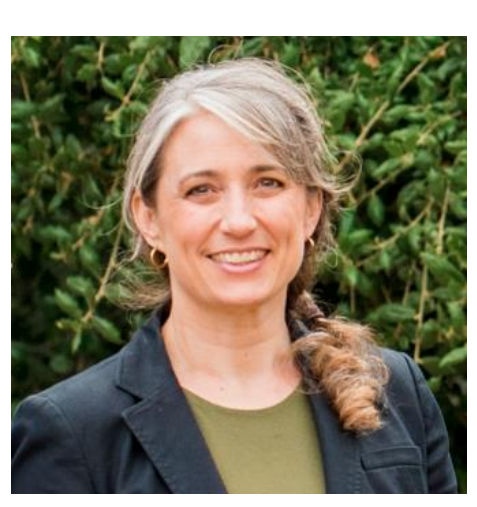

\section{About the Authors}

Stacy M. Kula, PhD is Associate Professor and the Director of the Educational Leadership EdD Program at Azusa Pacific University. Her work spans over 20 years as both a practitioner and researcher, with special emphasis on immigrant families. Her research interests include factors of achievement for low-income immigrant students, family-school-community partnerships, multilingual education, and effective teacher education for urban contexts. She has been awarded the Tae Kim Han Award for contributions to culture and humanity in her research. She has presented at national and international conferences and other venues. Her published works have focused on Latino and Southeast Asian immigration and educational experiences, as well as on international and multicultural teacher education experiences. She is co-editor and contributor of the recent publication, High-Achieving Latino Students: Successful Pathways Toward College and Beyond.
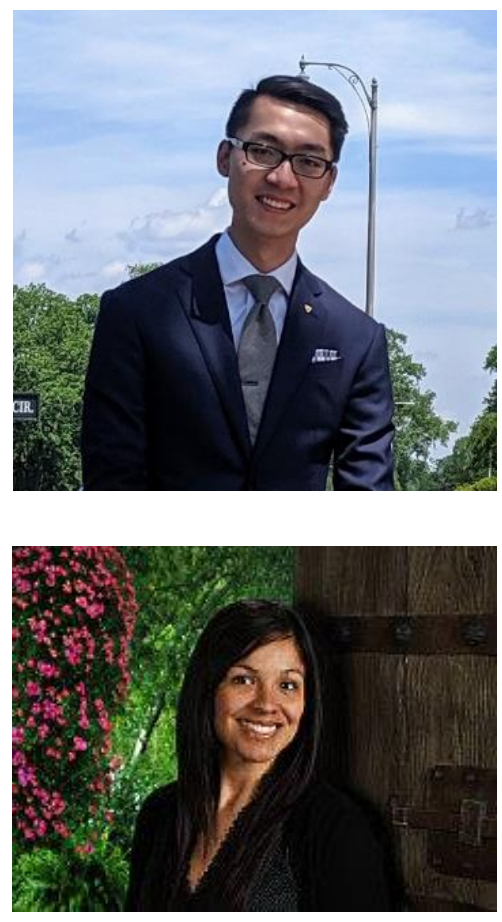

Vinh Q. Tran, MA, is a $\mathrm{PhD}$ Candidate of the School of Educational Studies at Claremont Graduate University. His current research interests include U.S. K-12 math and science education, interstate education policy exchange, and intra-national comparative education. He was awarded the Hsiao-Min Wang Award for his contributions to the research on Asian/Asian American culture and education. He has presented at environmental sciences conferences and his publications include works on afterschool STEM programs and Vietnamese American education.

Iraise Evelyn Garcia, MA, is a bilingual $\mathrm{PhD}$ student in Urban Leadership Education at Claremont Graduate University. She holds Masters degrees in Education and TESOL, and has worked in the K-12 educational system for over 17 years. She is currently a secondary school teacher for U.S. History, English, English Language Development, and Dual Immersion Social Studies, as well as an educational researcher. Her research interests are English Language learners, English development, family-schoolcommunity of immigrant students, and talent development. She has been awarded the Kathryn Z. Weed Endowed Fellowship, the Aubrey A. and Malcolm P. Douglass Memorial Fellowship, the Hsaio Min Wang Award, and the Tae Han Kim Award. She has been invited to speak at multiple higher education institutions on research methods, Vietnamese American education, and English language development. 


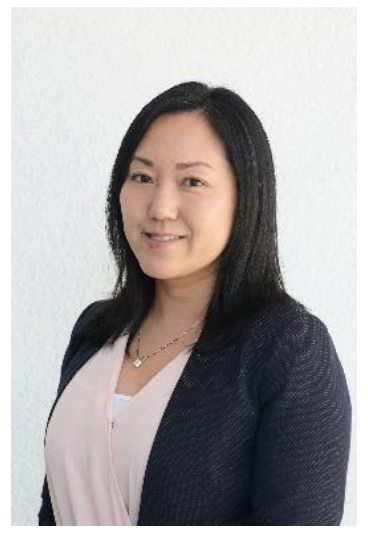

L. Erika Saito is an Assistant Professor at National University, College of Education, where serves as a Course Lead for the Master of Arts in two social emotional learning programs. Dr. Saito's background in education includes over 15 years as a classroom teacher, literacy TOSA, and ELD/Sheltered Programs Department Chair in both public and private institutions in Southern California. She currently holds a K-8 credential in the state of California, BA in English \& Humanities, minor in Ethnic Studies from University of Colorado at Boulder, MA in Education from Pepperdine University Graduate School of Education \& Psychology, and $\mathrm{PhD}$ in Education from Claremont Graduate University's School of Educational Studies. Her research and co-publications center on Asian American history, societal reception, generational status, and ethnic identity. Dr. Saito also serves on the Editorial Board for the Journal of Underrepresented and Minority Progress and as the Associate Editor for the Journal of Interdisciplinary Studies in Education.

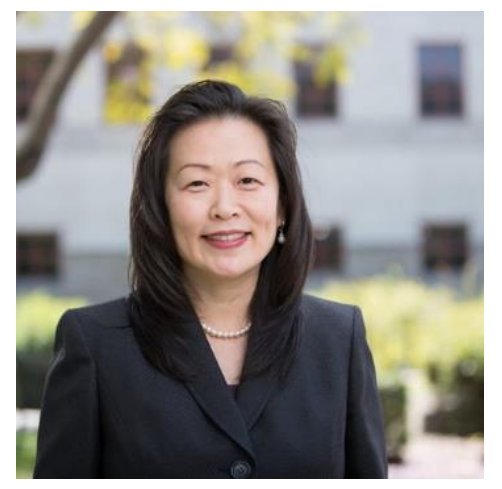

Susan J. Paik, PhD is a Professor in the School of Education at Claremont Graduate University. Her research includes talent and leader development, educational productivity, urban and international studies, methods and evaluation. Dr. Paik has participated in projects in Africa, Asia, Central America, Europe, and the United States. As an invited speaker, she has presented her work nationally and internationally in over 150 professional venues, including seminars for school leaders, teachers, parents, and students. She has received national fellowships, grants (e.g., AERA), and awards including the Early Outreach Award for her dedication to underserved students. Dr. Paik is an author or editor of various books and monographs such as Effective Educational Practices (IAE-IBE-UNESCO, 2000), Educational Productivity in South Korea and the United States (IJER, 2002), Advancing Educational Productivity (IAP, 2005), Narrowing the Achievement Gap: Strategies for Educating Latino, Black, and Asian Students (Springer, 2007), High-achieving Latino Students (IAP, 2020), and other works. 


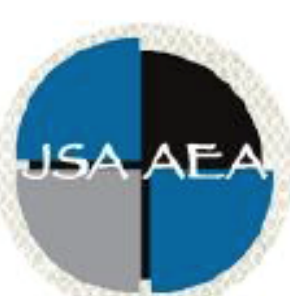

Vol.16 Iss.1 (2021)

\title{
Journal of Southeast Asian American \\ Education and Advancement
}

\author{
www.JSAAEA.org
}

\section{Editor}

Dr. Wayne E. Wright

Purdue University

Associate Editors

Dr. Chhany Sak-Humphry

University of Hawaii at Manoa

Dr. Phitsamay Sychitkokhong Uy

University of Massachusetts, Lowell

Book Review Editor

Dr. Vichet Chhuon

University of Minnesota

Creative Works Editor

Bryan Thao Worra

Lao Assistance Center

Journal Manager

Chen Li

Jeffrey Sovan Wright

Purdue University

\section{Editorial Review Board}

Dr. Steve Arounsack

California State University, Stanislaus

Dr. Sovicheth Boun

Salem State University

Dr. Virak Chan

Purdue University

Dr. Loan Dao

University of Massachusetts Boston

Dr. Linh Dang

KIPP DC Headquarters
Dr. Carl L. Bankston III

Tulane University

Dr. Phala Chea

Lowell Public Schools

Dr. George Chigas

University of Massachusetts, Lowell

Dr. Hien Duc Do

San Jose State University

Dr. Changming Duan

University of Missouri-Kansas City 


\author{
Dr. Sophal Ear \\ Occidental College \\ Dr. Vincent K. Her \\ University of Wisconsin, Eau Claire \\ Dr. Nancy H. Hornberger \\ University of Pennsylvania \\ Dr. Peter Tan Keo \\ New York University \\ Dr. Yvonne Kwan \\ San Jose State University \\ Dr. Ravy Lao \\ California State University, Los Angeles \\ Dr. Stacey Lee \\ University of Wisconsin, Madison \\ Dr. Jacqueline Mac \\ Northern Illinois University \\ Dr. Bic Ngo \\ University of Minnesota \\ Dr. Leakhena Nou \\ California State University, Long Beach \\ Dr. Mark Pfeifer \\ SUNY Institute of Technology \\ Dr. Loan T. Phan \\ University of New Hampshire \\ Dr. Karen Quintiliani \\ California State University, Long Beach \\ Dr. Angela Reyes \\ Hunter College \\ The City University of New York \\ Dr. Fay Shin \\ California State University, Long Beach \\ Dr. Christine Su \\ College of San Mateo \\ Dr. Alisia Tran \\ Arizona State University \\ Dr. Khatharya Um \\ University of California, Berkeley \\ Dr. Kim Tran \\ University of California, Los Angeles, \\ Glendale Community College \\ Dr. Molly Wiebe \\ The University of Texas at Austin
}

\author{
Dr. Sothy Eng \\ Lehigh University \\ Dr. Jeremy Hein
}

University of Wisconsin, Eau Claire

Dr. Peter Nien-Chu Kiang

University of Massachusetts, Boston

Dr. Kevin K. Kumashiro

University of Illinois, Chicago

Dr. Ha Lam

Independent Scholar

Dr. Jonathan H. X. Lee

San Francisco State University

Dr. Monirith Ly

Royal University of Phnom Penh

Dr. Sue Needham

California State University, Dominguez Hills

Dr. Max Niedzwiecki

Daylight Consulting Group

Dr. Clara Park

California State University, Northridge

Dr. Giang Pham

University of Massachusetts Amherst

Dr. Malaphone Phommasa

University of California Santa Barbara

Dr. Kalyani Rai

University of Wisconsin-Milwaukee

Dr. Cathy J. Schlund-Vials

University of Connecticut, Storrs

Dr. Nancy J. Smith-Hefner

Boston University

Dr. Yer J. Thao

Portland State University

Dr. Monica M. Trieu

Purdue University

Dr. Silvy Un

Saint Paul Public Schools

Dr. Linda Trinh Vo

University of California, Irvine

Dr. Varaxy Yi Borromeo

California State University, Fresno

Dr. Yang Sao Xiong

The University of Wisconsin-Madison

\section{Dr. Zha Blong Xiong}

University of Minnesota 


\section{Doctoral Student Editorial Review Board}

\section{Diana Chandara}

University of Minnesota-TwinCiteis

Linh Dang

University of Rochester

Annie BichLoan Duong

San Joaquin County Office of Education

Jacqueline Mac

Indiana University

Vanessa Sovanika Na

University of California SanDiego

Khoi Nguyen

George Mason University

Linda Marie Pheng

University of Wisconsin-Madison

Latana Thaviseth

University of California Los Angeles

Melissa Vang

San Diego State University

Soua Xiong

San Diego State University

Claremont Graduate University
Kassandra Chhay

University of Minnesota-Twin Cities

Bao Diep

University of Minnesota-Twin Cities

Nielson Hul

Cornell University

Dung Minh Mao

University of Minnesota-Twin Cities

Hoa Nha Nguyen

Boston College

Thien-Huong Ninh

University of Southern California

Krissyvan Truong

Claremont Graduate University

Mai Vang

University of Massachusetts Boston

Thong Vang

University of Minnesota-Twin Cities 